Salesian Journal of Humanities and Social Sciences, Vol. X, No. 1. (May 2019)

ISSN: 0976-1861 | DOI: 10.51818/SJHSS.10.2019.46-54 | Page: 46-54,

Section: Article

\title{
A Nation through Violence to Healing in Malsawmi Jacob's Zorami: A Redemption Song
}

Luhish Lushai is an Assistant Professor at the Department of English, Don Bosco College, Itanagar. His area of of interest and research is Nationalism and Women Studies with special focus on the postcolonial developing world and Northeast India.

\begin{abstract}
The last six decades for the northeast amid the vexed insurgency and the multi-pronged ethnic and linguistic conflicts could under no circumstance be really dismissed as the lost decades.1 Violence and insurgency has marred the face of Northeast India in the psyche of the mainland inhabitants. An insurgency is a rebellion against lawful authority, especially in armed resistance to a government or to the execution of its law. According to the data gathered by South Asia Terrorism Portal, the fatalities in terrorist violence in India's Northeast between the years 1992-2018, is 21566 of which 10290 civilian fatalities, 2749 security personnel and 8527 terrorists or insurgents. 2 The paper is an attempt to study and evaluate two decades of insurgency and violence. The paper analyses the novel Zorami as a historical narrative of the Mizos based on the postmodernist historiographic metafiction to the possibility of multiple representations of history.
\end{abstract}

Key Words: Northeast, Mizos, Violence, Insurgency, Zorami.

Although the Naga movement received wide publicity and has been extensively written about in the last sixty years, very little was available on the Mizo uprising both in terms of information and

${ }^{1}$ Dev Nirendra, The Talking Guns: North East India (New Delhi: Manas Publications, 2009), 28

2 "Fatalities in Terrorist Violence in India's Northeast 1992-2018" South Asia Terrorist Portal, accessed February 25, 2018, http://www.satp.org/satporgtp/ countries/india/database/fatalitiesnorteast2006.html 
understanding. It was the movements in Kashmir and Nagaland that were prominent in the history of dissent in modern India. Even after the uprising, the struggle of the Mizos found very little attention except few pieces in the Economic and Political Weekly which were critical about the state's gross violation of human rights in the Lushai Hills. ${ }^{3}$ The history of the Northeast region post independence is marred with blood and violence and many a times unrecorded or one sided records which did not take the people of the region into account.

For twenty years, the Mizo people had lived in fear of being branded rebels, and for twenty years, they refrained from writing diaries, creative outpourings or records of experiences because the dreaded soldiers who could not read the language were wont to brand these as "MNF documents." ${ }^{4}$

A lot of literature written before and during the years of insurgency was burnt either by the soldiers or by the writers/ owners themselves for fear of arrest or other worse consequences. It will forever be difficult to fill this gap. Malsawmi's Zorami: A Redemption Song (2015) has tried to fill that void with her work.

\section{A Postmodern Historiographic Metafictional Approach}

Postmodernist understanding of history demands for the subjectivity in the interpretation of historical events indicating that history is a construct that depends on the individual's understanding of it. Haydon White a famous historian challenges the distinction between historical and fictional narrative through structuralist and poststructuralist theories. In his Tropics Of Discourse: Essays in Cultural Criticism(1982), he writes, "Although historians and writers of fiction may be interested in different kinds of events, both the forms of their respective discourses and their aims in writing are

${ }^{3}$ J. V. Hluna and Rini Tochhawng, The Mizo Uprising: Assam Assembly Debates on the Mizo Movement, 1966-1971, Vol. IX (Newcastle: Cambridge Scholars Publishing, 2012).

${ }^{4}$ J. V. Hluna and Rini Tochhawng, The Mizo Uprising: Assam Assembly Debates on the Mizo Movement, 1966-1971, Vol. XI-XII (Newcastle: Cambridge Scholars Publishing, 2012). 


\section{8 / Luhish Lushai}

Salesian Journal of Humanities and Social Sciences, Vol. X, No. 1. (May 2019) ISSN: 0976-1861 | DOI: 10.51818/SJHSS.10.2019.46-54 | Page: 46-54,

Section: Article

often the same." ${ }^{5}$ In addition, the techniques or strategies that these writers use in the composition of their discourses are substantially the same.

"Historiographic metafiction" is a term coined by Canadian literary theorist Linda Hutcheon in the late 1980s. The term is used for works of fiction, which combine the literary devices of metafiction with historical fiction. According to Hutcheon, in $A$ Poetics of Postmodernism, works of historiographic metafiction are those well-known and popular novels which are both intensely selfreflexive and yet paradoxically also lay claim to historical events and personages. It is obsessed by history; it is concerned with historical events, it makes history its subject and reflects on historiography. It combines metafictional elements with particular and deep attention to history, including three genres, literature, history and theory, as one. It is exactly the literary, self-conscious combination of history and fiction. Postmodern theory challenges the separation of the literary and the historical: they are both modes of writing, linguistic constructs and intertextual. It raises the issue of what writing about history implicates, questioning the sense and the various possible interpretations of the past. Hutcheon argues that historiographic metafiction is inherently contradictory: it works within conventions in order to subvert them. While claiming reference to the historical world, it doubts and plays with such a world. Historiographic metafiction must live with the double awareness of its fictionality and its foundation in real events. It suggests that "[T]ruth and falsity may indeed not be the right terms in which to discuss fiction, for the postcolonial historical novels openly assert that there are only truths in the plural, and never one Truth; and there is rarely falseness per se, just others' truths." ${ }^{6}$

Postmodern historical novels critically revisit the past; their interest in what has been before does not simply tally with a nostalgic return. They are concerned with the effects of historical forces on the lives of individual characters: to be recorded are the

${ }^{5}$ Hayden White, Tropics Of Discourse: Essays In Cultural Criticism (Baltimore: The John Hopkins U P, 1978), 121.

${ }^{6}$ Linda Hutcheon, The Poetics of Postmodernism (London: Routledge, 1989), 109. 
experience of great historical events and their consequent traumas. Contemporary experience is permeated by the past; therefore, the focus of the novels is on both the movement of history and the rhythms of ordinary life. In postmodern novels, historical events are proved to be deeply influencing the way in which the characters construct their understanding of their personal and national pasts in the present. They ask how to imagine the future unfolding from the past, inviting the reader to reflect on received versions of history. The process of building identity is connected to such reflection on the past. Postmodern historical novels question the received narratives of national identity.

Central to these novels is the question of how we imagine history, focusing on the limits and powers of reporting or rewriting the past. The investigation of the past is based on the longing to pinpoint the processes of representation that forms history. Historiographic metafiction reveals the constructed, imposed nature of meaning; it plays upon the truth and lies of any historical record. With the presence of many possibilities of meaning, Hutcheon believes that it is able to confront reality, though she does not consider reality as a single, graspable entity. Reality can be known only through its cultural representations. Postmodern historical novels also speak about the ability of fiction to approach truth in their accounts of past events. Throughout the novels, the characters seek to understand their own selves in historical terms, finding some reassurance from the consciousness that there is a history behind them, obtaining some certainty from the awareness that they have something behind to look at and confront with. Historiographic consciousness is based on the development of the past; it is interested in who had the power to compose truths about the past. If postmodern fiction does not aspire to tell the truth, at least it questions whose truth has hitherto been told.

\section{Problematizing History in Zorami: A Redemption Song}

Zorami: A Redemption Song, tells the story of a woman named Zorampari, who had been sexually assaulted when she was a teenager by an Indian army man during Mizo insurgency. Her 


\section{0 / Luhish Lushai}

Salesian Journal of Humanities and Social Sciences, Vol. X, No. 1. (May 2019) ISSN: 0976-1861 | DOI: 10.51818/SJHSS.10.2019.46-54 | Page: 46-54,

Section: Article

psyche is damaged by the trauma and she cannot recover even in late adulthood, until an unexpected turn occurs. She represents the Mizo people and her story is their story as they go through insurgency and army atrocities. The story is told in a non-linear manner to represent the chaotic condition that Mizoram went through. Fear, pain, resentment, and acute loss, these emotions have marred the everyday existence of generations of Mizo people, who have lived through turbulent years of insurgency, the impacts of which are fresh in their memory even today. The novel also throws light on Mizo history, culture and folklore.

Malsawmi Jacob takes us back to the past and evokes the history that is buried in the memories of the nation. Malsawmi says, "We are a very young nation as a people group". The Mizo community has always viewed themselves as belonging to a nation and as Benedict Anderson, in his monumental work, Imagined Communities (1983), argues that the nation exists only in the minds of the people who regard themselves as belonging to one nation. This is because nobody in a nation has ever met, and will never meet, the whole people in his nation, yet in the mind of each exists the imagining of his communion. The MNF movement was a nationalist movement, a process of self-discovery, self-transcending; it was a permanent manifestation of humanity unfolding for a "people group."

Zorami has been one of the most painful stories Malsawmi has given words to, one that took her nearly a decade to pen. In the interview by Shweta Raj Kanwar of The Northeast Today, Malsawmi Jacob says how the novel Zorami came about:

The Mizo insurgency that broke out in 1966, and the counterinsurgency operations by the Indian Army, with its blood-curdling horrors, are something the Mizo people cannot forget. A 'peace accord' was signed in 1986 and political peace returned. But those who had suffered during the period were still hurting inside. For dealing with the inner conflicts, the fiction format feels more suitable than non-fiction. Hence, the novel.

The reason she says that she would simply go "numb with pain" listening to the recorded interviews of the people who had lived 
through the most traumatic period in Mizo history, on which the narrative is based. Malsawmi has drawn on the insurgency years of the sixties, when the Mizo Liberation Front (MLF) was at its peak, to tell the story of young Zorami.

Malsawmi journeys us through the memory lane along with Zorami as she reminiscences the dreaded mautam (the great famine) as people begin to express their hyperbolicfear, "Rats are multiplying fast. They say in some places even other creatures like caterpillars and snails are turning into rats." 7 The growing unrest emanated anti-Indian feeling because of the indifference of Government and they begin to say, "It was a mistake to become part of India." As a small girl, she along with her friend Kimi participates in the protest rally holding placards and shouting, "We do not want Assamese language! We do not want goblin-scripts! Down with vai rule!"

Zorami a middle aged married woman with no children and a shattered past cannot accept the peace that prevails over her land. She cannot accept that her friend and friend's family could forgive the persons responsible for her father's death. She says, "How could they allow their father's murderers to live in peace?... We have lost our fighting spirit since the Indian army trampled us flat during the freedom fight." ${ }^{8}$ As she suffers in the depth of her psyche the traumatic pangs that keeps haunting her.

Broken? She was lacerated, ripped apart. A fiend in human body did it in revolting lust. When the thirteen year old did not come back from the tuikhur where she had gone to fetch water, her worried mother took a couple of neighbours with her and went in search of her daughter. They found her unconscious, her dress torn and soaked with urine and blood, in the bushes. In the hospital, after she regained consciousness, a nurse stitched her up. Without anesthesia. How she screamed! The needle pierced her again and again. Stinging pain upon pain.

${ }^{7}$ Jacob Malsawmi, Zorami: A Redemption Song (London: Morph Books, 2015), 50.

${ }^{8}$ Jacob Malsawmi, Zorami: A Redemption Song, 160. 


\section{2 / Luhish Lushai}

Salesian Journal of Humanities and Social Sciences, Vol. X, No. 1. (May 2019) ISSN: 0976-1861 | DOI: 10.51818/SJHSS.10.2019.46-54 | Page: 46-54,

Section: Article

And the dirt, the dirt! How she wanted to wash herself clean, to be immersed in a flowing river! But there was no such river within reach. All she could get was a few mugs of water for a bath. She loathed her defiled body like a rotten carcass. In sleep, she dreamt of a brook running down a hill. She ran to it, hoping for a dip in its clear, clean water. But when she reached there, she saw only muddy, filthy water. ${ }^{9}$

The movement that began with Mizo National Front turned violent. The narrator recaptures the emotions of the nation in her people. The bombing of Aizawl city by the IAF Hunter and Toofani fighter jets, which many people in our country are unaware of like the people living in England really never knew what went on in the Indian subcontinent, and the fear of the people is captured in the book. Zorami's mother tells her, "Call the children and get them ready. We have to run away from here. There's going to be war between the MNF and the Assam Rifles" . Malsawmi has depicted the atrocities carried out by the Armed Forces with the help of Armed Forces Special Power Act. Mizo historian Lalrimawia records in his book, Mizoram: History and Cultural Identity (1995) that the Indian Government started the "Operation Security" in 1967 which declared the Mizo National Front as illegal. The SilcharAizawl-Lunglei road was populated with fifty thousand Mizos from hundreds of villages, which were burnt down by the Indian Army, in eighteen group centres styled as Progressive Protected Village. ${ }^{10}$ Malsawmi brings out the traumatic experience of the people who were relocated to the Silchar-Aizawl-Lunglei road sides and their villages burnt down so that they could not give shelter to MNF soldiers.

As the reminiscence of Zorami progresses so does the intensity of her traumatic experience. Malsawmi in an interview to Ninglun Hanghal, she said:

${ }^{9}$ Ibid., 145.

10 Lalrimawia, Mizoram: History and Cultural Identity (Guwahati: Spectrum Publications, 1995), 137. 
The story of Mizo people, especially what they went through during those turbulent times, is important. I used to wonder how they were dealing with the psychological trauma of the time even though 'political peace' had returned. After listening to many people, I realised that the emotional wounds had not healed. So the novel is a quest for inner healing." 11

Zorami represents Malsawmi's Mizoram. Though she has narrated the experience of various characters including the legendary $\mathrm{Pu}$ Laldenga, the leader of the MNF and also the First Chief Minister of Mizoram, after the peace accord, it is Zorami who is our center of discourse. We are glued to her as she becomes the symbol of Mizoram. In fact, Mizoram is generally called by its inhabitants as Zoram and ' $i$ ' is the suffix that is added to every girl's name. We are curious to know whether Zorami will ever recover or heal. The author brings about a spiritual turn to the story. An inner healing takes place as Zorami surrenders to divine intervention as she fully accepts herself and gives herself to Sanga, her husband, in love and reconciliation.

Lalmawia writes, "Many years will be required to heal these fatal wounds of the Mizos and nothing seems to be too big or too great if it is a right medicine which will completely cure all these severe wounds." 12 Malsawmi asserts, "Inner healing has to come at a personal level. Perhaps a divine intervention would make a difference, like in Zorami's story." ${ }^{13}$

\section{Conclusion}

In the light of this analysis of Zorami: A Redemption Song, it can be seen that the writer uses postmodern and metafictional aspects of her novel to subvert the monolithic discourse of history. The study has analyzed, in line with the postmodernist view of historiography and historical novel, Rushdie's Shame as "Historiographic

\footnotetext{
${ }^{11}$ Ninglun Hanghal, "Meet Malsawmi Jacob - First Mizo Author to Write an English Language Novel", The Better India, updated June 12, 2016, https:/ / www. thebetterindia.com/57733/giving-words-voice-mizo-women/.

${ }^{12}$ Lalrimawia, Mizoram: History and Cultural Identity, 136.

${ }^{13}$ Malsawmi, Zorami: A Redemption Song.
} 


\section{4 / Luhish Lushai}

Salesian Journal of Humanities and Social Sciences, Vol. X, No. 1. (May 2019) ISSN: 0976-1861 | DOI: 10.51818/SJHSS.10.2019.46-54 | Page: 46-54, Section: Article

Metafictions" and it has been claimed that this text of the novelist includes historical material along with metafictional self reflexivity.

In Zorami, the decentralizing of the great historical figures in history is achieved by the writer this time by means of rewriting the recent political history of Mizoram through the perspectives of her peripheral characters. The history of Mizoram is told simultaneously with the stories of the people who are victims of past events in the novel. In Malsawmi's counter-narrative, the individual plays an active role and vies for the centre, and his/her voice is in conflict with that of the dominant. Therefore, the monolithic discourse of history can be opened to multi-vocality in Malsawmi's novel. 